\title{
Konsep Etika Epikuros dan Problem Media Sosial
}

\author{
Muh. Bahrul Afif \\ UIN Sunan Kalijaga Yogyakarta \\ muhbahrulafif@gmail.com
}

Abstract : In the last few decades, one of the ethical problems that has taken a lot of public attention is the hoax problem on social media. Social media, which was originally created as a medium to facilitate the delivery of messages and information, is actually being misused to spread false news which eventually breeds hatred and animosity. One philosopher who is famous for his thoughts on ethical concepts, namely Epicurean. This article will discuss how the Epikuros ethical concept and its relevance to social media problems. This paper is classified in library research and uses the hermeneutical descriptive method. The typology of Epicuros thought belongs to the ethical theory of hedonism, Epicurean in its ethical thought establishes pleasure or pleasure (hedone) as the highest ideal in human life. The intended enjoyment is not only from the material aspect, but the most important thing is the enjoyment of the soul which is referred to as ataraxia. To achieve ataraxia that is by trying to avoid suffering and anxiety. According to Epicureans, in order to avoid suffering and anxiety, humans must have the attitude of phronesis or prudence, which is interpreted as an attitude of vigilance. When connected with social media problems, this attitude of vigilance is very relevant and important to be owned by every individual as a user of social media, so as not to become part of the chain of hoax distribution.

Keywords : Epikuros, Etika, Hedonisme, Phronesis, Hoax

Abstrak : Dalam beberapa dekade terakhir ini, salah satu problem etis yang banyak menyita perhatian publik ialah problem hoax di media sosial. Media sosial yang semula diciptakan sebagai 
media untuk memudahkan dalam menyampaikan pesan dan informasi, justru disalahgunakan untuk menyebarkan berita bohong yang akhirnya melahirkan kebencian dan permusuhan. Salah seorang filusuf yang terkenal dengan pemikirannya tentang konsep etika yakni Epikuros. Artikel ini akan membahas bagaimana konsep etika Epikuros dan relevansinya terhadap problem media sosial. Tulisan ini tergolong dalam penelitian kepustakaan dan menggunakan metode deskriptif hermeneutis. Tipologi pemikiran Epikuros tergolong dalam teori etika hedonisme, Epikuros dalam pemikiran etikanya menetapkan kesenangan atau kenikmatan (hedone) sebagai ideal tertinggi dalam kehidupan manusia. Kenikmatan yang dimaksud tidak hanya dari aspek materi saja, melainkan yang paling penting adalah kenikmatan jiwa yang disebut sebagai ataraxia. Untuk mencapai ataraxia yakni dengan berusaha menghindari penderitaan dan kecemasan. Menurut Epikuros supaya terhindar dari penderitaan dan kecemasan manusia harus memiliki sikap phronesis atau prudence, yang dimaknai sebagai sikap kewaspadaan. Jika dihubungkan dengan problem media sosial, sikap kewaspadaan ini sangat relevan dan penting dimiliki oleh setiap individu sebagai pengguna media sosial, agar tidak turut menjadi bagian dari mata rantai penyebaran hoax.

Kata Kunci : Epikuros, Etika, Hedonisme, Phronesis, Hoax

\section{A. Pendahuluan}

Manusia pada dasarnya adalah makhluk yang selalu disibukkan dengan keinginan mencapai ideal tertinggi dalam kehidupannya. Sebagai makhluk yang dianugerahi akal untuk mencapai tujuan tersebut, manusia merumuskan cara yang harus ditempuh dan setiap orang memiliki pemikiran yang berbeda-beda. Hal ini menyebabkan pemaknaan terhadap kebaikan tertinggi atau kualitas kehidupan yang ingin dicapai pun menjadi berbeda, termasuk cara yang harus ditempuh untuk mencapainya. Dengan demikian, maka dapat dikatakan bahwa manusia dalam kehidupannya lebih banyak bergelut dalam persoalan etis.

Dalam beberapa dekade terakhir ini, tendensi etika mengarah kepada berbagai problem yang bersifat aktual. Berbagai persoalan yang berakar dari dekadensi moral kian menyeruak baik dalam skala nasional, maupun dalam skala global. Diantara permasalahan 
teknologi yang akhir-akhir ini menyita perhatian publik adalah media sosial. Sebagai salah satu wujud revolusi dalam bidang teknologi informasi dan komunikasi, media sosial tentu disepakati memberikan banyak kemudahan bagi manusia sebagai penggunanya. Ia menjadi cyberspace yang mengantarai penggunanya, tidak hanya dalam berkomunikasi, tetapi juga untuk mengakses berbagai hal ${ }^{1}$. Namun, berbagai kemudahan dan juga keleluasaan yang ditawarkan itu kini menjadi problem etis, ketika didapati banyaknya penyalahgunaan dalam memanfaatkannya. Melihat kenyataan bahwa "ruang" tersebut menjadi tempat munculnya berbagai problem sosial yang serius, salah satunya adalah penyebaran berita bohong atau hoax.

Dalam situasi sekarang, tidak berlebihan bila dikatakan bahwa kajian etika menjadi sangat penting untuk dilakukan. Etika tidak hanya membuka jalan menuju kehidupan manusia yang bermutu, melainkan juga menyediakan orientasi hidup yang jelas. Sebab, kebutuhan manusia yang paling fundamental adalah orientasi. Manusia harus mengetahui dimana dan kemana ia harus bergerak untuk mencapai tujuannya. Etika dalam hal ini adalah sarana orientasi bagi usaha manusia untuk menjawab berbagai pertanyaan yang fundamental, seperti bagaimana saya harus hidup dan bertindak? Maka tidak heran jika pembahasan mengenai etika ini sudah ada sejak dahulu, salah satu filusuf yang secara serius mengkaji tentang etika dan melahirkan konsep etika secara mandiri yaitu Epikuros. Dalam ajaran etikanya, Epikuros melihat kesenangan atau kenikmatan (hêdonê) sebagai ideal tertinggi dan menjadi tujuan hidup manusia. Melihat hal ini, para sarjana filsafat menetapkan corak pemikiran etika Epikuros termasuk dalam teori etika hedonisme. Meskipun corak etika hedonisme sebelumnya dengan etika hedonisme yang dikembangkan Epikuros memiliki perbedaan yang sangat jelas.

Pemikiran Epikuros memang telah ada yang mengkaji, antara lain: Muh. Akmal Ahsan, ${ }^{2}$ Sri Sudarsih, ${ }^{3}$ Rial Ashari. ${ }^{4}$ Beberapa

${ }^{1}$ Jeff Zaleski, Spiritual Cyberspace (Bandung: Mizan, 1999), h. 10.

${ }^{2}$ Muh. Akmal Ahsan, https://lsfdiscourse.org/merayakan-hidup-hedonisala-epikuros/, diakses Tanggal 20 September 2019. 
tulisan yang peneliti temukan masih dalam bentuk makalah yang upload di website dan belum diterbitkan di Jurnal. Dalam artikel ini peneliti akan membahas bagaimana konsep etika Epikuros dan relevansinya terhadap pemecahan problem media sosial? Penelitian ini tergolong dalam penelitian pustaka dan menggunakan metode diskriptif analisis. Phronesis atau Kewaspaan sebagai kata kunci yang ditawarkan dalam konsep etika Epikuros sangat relevan dengan solusi yang dibutuhkan terkait dengan masalah media sosial.

\section{B. Memahami Makna Etika}

Term etika dapat dikatakan tidak asing lagi bagi kebanyakan orang. Term ini bukan lagi hanya digunakan di kalangan intelektual, namun juga mungkin sering didengar penggunaannya dalam obrolan sehari-hari. Penggunaannya sering kali dipadankan dengan istilah lain seperti moral dan adab, sehingga seolah memiliki makna yang sama. meskipun jika ditinjau lebih jauh, maka makna dari istilah tersebut memiliki perbedaan yang cukup jauh.

Secara etimologis, sebagaimana term lain dalam konteks ilmiah, etika berasal dari kata dalam bahasa Yunani Kuno yaitu ethos, dalam bentuk jamak adalah ta etha. Kata ethos memiliki banyak arti: tempat tinggal yang biasa; padang rumput, kandang, habitat; kebiasaan, watak; perasaan, sikap, cara berpikir. Adapun dalam bentuk jamaknya, ta etha, berarti adat kebiasaan. Kata terakhir inilah yang menjadi latar belakang terbentuknya istilah etika sebagaimana yang dikenal sekarang, dan digunakan oleh Aristoteles untuk menunjukkan filsafat moralnya (ethikos). Maka berdasarkan asalusulnya, kata etika dapat diartikan sebagai ilmu tentang apa yang biasa dilakukan atau ilmu tentang adat kebiasaan. ${ }^{5}$

${ }^{3}$ Sri Sudarsih, Konsep Hedonisme Epikuros Dan Situasi Indonesia Masa Kini, $\quad$ https://media.neliti.com/media/publications/5053-ID-konsep-hedonismeepikuros-dan-situasi-indonesia-masa-kini.pdf, diakses Tanggal 20 September 2019.

4 Rial Ashari, https://medium.com/@Rial_Ashari/menjadi-epikureanac0cbfef2b6d, diakses Tanggal 20 September 2019.

${ }^{5}$ K. Bertens, Etika (Yogyakarta: Kanisius, 2013), h. 3-4. 
Sedangkan jika dilihat dari pengertian terminologisnya. Dalam Kamus Bahasa Indonesia, etika memiliki tiga pengertian. Pertama, etika adalah ilmu tentang apa yang baik dan apa yang buruk dan tentang hak serta kewajiban moral. Kedua, kumpulan asas atau nilai yang berkenaan dengan akhlak. Ketiga, asas perilaku yang menjadi pedoman. ${ }^{6}$ Satu lagi pengertian yang perlu dicantumkan sebagaimana dikutip oleh Bertens, bahwa etika adalah nilai mengenai benar dan salah yang dianut oleh suatu golongan atau masyarakat ${ }^{7}$.

Dari beberapa pengertian tersebut, etika dapat dirumuskan pengertiannya ke dalam tiga kategori, yaitu etika sebagai sistem nilai, etika sebagai kode etik dan etika sebagai ilmu. Etika dimaksudkan sebagai sistem nilai apabila ia berupa nilai-nilai yang bersifat normatif dan menjadi asas, pegangan maupun pedoman dalam komunitas tertentu dalam mengatur perilakunya. Etika dimaksudkan sebagai kode etik apabila ia menjadi kumpulan pedoman yang bersifat teknis dan praktis serta diberlakukan dalam mengontrol perilaku. Sedangkan etika berkedudukan sebagai ilmu apabila ia bercorak sistematis-ilmiah dan dimaksudkan untuk menyelidiki perihal baik maupun buruk serta tentang hak dan kewajiban moral. Maka dalam pengertian yang terakhir ini, etika disebut sebagai filsafat moral atau refleksi filosofis tentang moral. ${ }^{8}$

Kata lain yang sering dipadankan dengan istilah etika adalah moral. Dari pengertian akar katanya, keduanya memang memiliki arti yang sama, namun berbeda dari segi bahasa. Berbeda dengan etika yang berasal dari bahasa Yunani, moral berasal dari bahasa Latin, mores, yang merupakan bentuk jamak dari kata mos yang berarti adat istiadat, watak, kelakuan, tabiat dan cara hidup ${ }^{9}$. Dari segi istilah, moral berarti ajaran tentang baik buruk yang diterima umum

${ }^{6}$ Tim Penyusun Kamus Pusat Bahasa, Kamus Bahasa Indonesia (Jakarta: Pusat Bahasa, 2008), h. 402.

${ }^{7}$ K. Bertens, Etika, h. 4.

${ }^{8}$ Imam Iqbal, "Menjelajahi Etika: Dari Arti Hingga Teori," dalam Etika: Perspektif, Teori dan Praktik (Yogyakarta: FA Press, 2016), h. 5. Lihat juga Bertens, Etika, h. 5-6. 62.

${ }^{9}$ Jan Hendrik Rapar, Pengantar Filsafat (Yogyakarta: Kanisius, 2015), h. 
mengenai perbuatan, sikap, kewajiban dan sebagainya. ${ }^{10}$ Sebagai sebuah ajaran yang diterima secara umum sebagai pedoman dalam berperilaku, maka moral menunjuk kepada etika sebagai sistem nilai.

Meskipun sebagai sistem nilai kata etika dan moral memiliki persamaan, namun terdapat perbedaan di antara keduanya. Sidi Gazalba sebagaimana dikutip Imam Iqbal membedakan kedua istilah ini, bahwa moral bersifat praktis, sedangkan etika bersifat teoretis. ${ }^{11}$ Maka dalam distingsi tersebut, dapat dilihat bahwa etika yang dimaksud adalah etika sebagai ilmu. Hal ini pun sejalan dengan pandangan Franz Magnis-Suseno, bahwa etika merupakan pemikiran kritis dan mendasar tentang ajaran dan pandangan moral. Ia adalah ilmu, bukan sebuah ajaran. Etika, oleh sebab itu, bersumber dari refleksi yang dilakukan manusia, sedangkan moral berasal dari tradisi dan adat istiadat, ajaran agama atau ideologi tertentu. ${ }^{12}$

Etika oleh beberapa atau bahkan kalau boleh dikatakan hampir semua filsuf maupun sarjana filsafat dimasukkan ke dalam cabang dari filsafat. Secara umum, filsafat dibagi ke dalam enam cabang, yaitu epistemologi, metafisika, logika, etika, estetika dan filsafat tentang berbagai disiplin ilmu ${ }^{13}$. Dalam klasifikasi filsafat yang diberikan oleh Aristoteles, ia membagi filsafat ke dalam tiga bidang studi, yaitu filsafat spekulatif atau teoretis, filsafat praktika dan filsafat produktif. Etika digolongkan ke dalam filsafat praktika bersama dengan politik, yaitu filsafat yang memberikan petunjuk bagi tingkah laku manusia yang baik. ${ }^{14}$ Salah satu dari cabang filsafat ini terus mendapat perhatian besar dari para filsuf sejak perkembangan awal filsafat di Yunani sebagai tempat lahirnya filsafat hingga saat ini.

\footnotetext{
${ }^{10}$ Tim Penyusun Kamus Pusat Bahasa, Kamus Bahasa Indonesia, h. 1041.

${ }^{11}$ Imam Iqbal, "Menjelajahi Etika, h. 7.

${ }^{12}$ Franz Magnis Suseno, Etika Dasar: Masalah-Masalah Pokok Filsafat Moral (Yogyakarta: Kanisius, 2014), h. 14.

${ }^{13}$ Jan Hendrik Rapar, Pengantar Filsafat, h. 36.

${ }^{14}$ ibid., 34.
} 


\section{Sejarah Kajian Etika}

Persoalan etika pada zaman Yunani kuno dibicarakan secara intens oleh para filusuf. Hal ini dapat dilihat dengan munculnya berbagai sistem etika dalam pemikiran beberapa filusuf sepanjang sejarah Yunani kuno, yaitu sejak zaman pra-Sokrates hingga pascaAristoteles zaman Helenistis. Intensitas pembicaraan etika yang besar ini tidak terlepas dari pertalian yang erat antara etika dengan kehidupan manusia. Sebab dengan etika manusia mampu mengetahui tindakan apa yang harus dilakukan untuk meraih kehidupan yang lebih berkualitas.

Di zaman pra-Sokrates pemikiran tentang etika muncul pertama kali di kalangan murid-murid Phytagoras ${ }^{15}$. Meskipun Phytagoras tidak menuliskan apapun mengenai ajarannya, pemikirannya hidup di kalangan murid-muridnya lewat tradisi lisan yang bersifat rahasia. Barulah pada sekitar pertengahan abad ke-5 S.M. ajarannya mulai terdengar ${ }^{16}$. Ideal tertinggi bagi Phytagoras dan murid-muridnya adalah ketika jiwa yang dianggap kekal setelah kematian terbebas dari nasib reinkarnasi. Menurut mereka perpindahan jiwa secara terus-menerus baik kepada hewan, tumbuhan maupun manusia merupakan sebuah hukuman, sebab tubuh dianggap sebagai suatu belenggu bahkan kuburan bagi jiwa. Maka untuk luput dari reinkarnasi itu, seseorang harus menempuh jalan katarsis (penyucian diri) dengan tidak melakukan hal-hal yang menjadi pantangan, seperti tidak memakan daging hewan atau kacangkacangan.

Gagasan etika juga ditemukan dalam pemikiran Demokritos meskipun belum dalam bentuk sistematis. Filsuf atomis ini memberikan pengajaran mengenai ideal tertinggi dalam hidup manusia yang disebutnya sebagai euthymia. Euthymia diartikan sebagai keadaan batin yang sempurna. Ia dicapai dengan prinsip keseimbangan, dalam arti seseorang harus menyeimbangkan segala faktor dalam hidupnya. Kesenangan menjadi ukuran dalam tingkah

${ }^{15}$ Imam Iqbal, "Menjelajahi Etika, h. 8.

${ }^{16}$ Harun Hadiwijono, Sari Sejarah Filsafat Barat I (Yogyakarta: Kanisius, 2001), h. 19. 
laku manusia. Namun, kesenangan yang dimaksud bukan semata bersifat material, tetapi juga mendatangkan ketenangan bagi jiwa ${ }^{17}$.

Plato yang dikenal sebagai seorang filsuf besar di zamannya bahkan hingga hari ini diketahui juga memiliki pandangan mengenai etika, meskipun tidak meninggalkan satu karya pun yang secara khusus membahas tentang etika. Namun, sejauh pembacaan terhadap pemikiran Plato, dapat disimpulkan bahwa ia pun memiliki pandangan mengenai ideal tertinggi yang dapat dicapai oleh manusia dengan cara tertentu. Baginya, ideal tertinggi adalah Sang Baik dan makna keberadaan manusia adalah untuk mencapai ideal tertinggi dengan pengenalan akal budi dan membebaskan diri dari kekuasaan hawa nafsu ${ }^{18}$. Selain itu cinta (eros) juga sangat berperan penting dalam upaya tersebut. Eros adalah daya kreatif dalam diri manusia yang mampu mendorongnya melampaui kecintaan terhadap keindahan material menuju kecintaan terhadap keindahan yang ideal Sang Baik, ilahi ${ }^{19}$.

Kajian etika yang lebih terperinci dan sistematis selanjutnya ditemukan dalam pemikiran-pemikiran murid Plato, Aristoteles. Berbeda dengan gurunya, ia banyak menulis karya yang secara khusus membahas mengenai etika: Ethica Eudemia; Ethica Nikomacheia; Politica; dan Magna Moralia meskipun karya terakhir ini masih diragukan otentisitasnya. Bertens mengatakan bahwa pemikiran Aristoteles yang lebih matang tentang etika ditemukan dalam Ethica Nikomacheia sebab ditulis di usianya yang lebih tua dibandingkan saat menulis Ethica Eudemia ${ }^{20}$. Sedangkan karyanya Politica dapat digolongkan dalam karya etika sebab memiliki keterkaitan dengan persoalan etika ${ }^{21}$. Alasan dari penggolongan tersebut menurut penulis mungkin saja didasari pandangan bahwa pemikirannya tentang politik juga termasuk dalam filsafat praktika sebagaimana dalam klasifikasi filsafat Aristoteles yaitu menyangkut

\footnotetext{
${ }^{17}$ K. Bertens, Sejarah Filsafat Yunani (Yogyakarta: Kanisius, 1989), h. 66.

${ }^{18}$ Imam Iqbal, "Menjelajahi Etika, h. 9.

${ }^{19}$ P. A. Van der Weij, Filsuf-Filsuf Besar Tentang Manusia, trans. oleh K. Bertens (Jakarta: PT Gramedia Pustaka Utama, 2017), h. 27.

${ }^{20}$ K. Bertens, Sejarah Filsafat Yunani, h. 159.

${ }^{21}$ Ibid., h. 166.
} 
bagaimana seseorang harus bertindak. Pemikiran Aristoteles dalam bidang etika menjadi arus utama dan memengaruhi pandangan etis beberapa filsuf yang hidup dalam beberapa abad setelahnya.

Menurut Aristoteles, ideal tertinggi dalam kehidupan manusia adalah kebahagiaan (eudaimonia). Hal inilah yang menjadi tujuan hidup manusia. Maka untuk mencapai kebahagiaan tersebut, ada dua syarat yang harus dipenuhi yaitu keterlibatan aktif dalam aktivitas (praxis) atau mengaktualisasikan potensi diri sebagai makhluk sosial dan tindakan yang didukung oleh keutamaan-keutamaan (aretê). ${ }^{22}$

Perbincangan mengenai etika tetap mengalir dalam tradisi filsafat pada zaman Helenistis pasca-Aristoteles. Zaman Helenistis ini menurut Russell adalah zaman lahirnya karya-karya terbaik dalam bidang ilmu pengetahuan dan matematika yang pernah dicapai oleh bangsa Yunani. Dalam bidang filsafat, zaman ini juga dinilai penting bagi perkembangan filsafat, meskipun tidak sepenting pada zaman Plato dan Aristoteles. ${ }^{23}$ Pada zaman ini lahir mazhab Epikurean, Stoisisme dan aliran Skeptisisme awal yang juga menaruh perhatian terhadap persoalan etika. Aliran Stoisisme didirikan oleh Zeno, sedangkan Epikurean didirikan oleh Epikuros yang akan dibahas pemikiran etikanya lebih lanjut dalam tulisan ini.

\section{Biografi Singkat Epikuros}

Keterangan mengenai kehidupan personal Epikuros bisa dikatakan tidak selengkap dan serinci bila dibandingkan dengan keterangan hidup filsuf besar Yunani lainnya, khususnya Plato ataupun Aristoteles, yang bisa begitu mudah ditemukan dalam bukubuku sejarah filsafat. Sumber referensi yang menjelaskan hal tersebut menurut penulis terbilang masih terbatas. Mungkin inilah salah satu alasan mengapa pembicaraan tentang tokoh ini masih jarang dilakukan. Namun yang pasti, tentu masih ada sumber yang bisa dijadikan acuan dalam menjelaskan kehidupan Epikuros. Menurut Russell, narasumber utama untuk memperoleh keterangan mengenai

${ }^{22}$ Imam Iqbal, "Menjelajahi Etika, h. 10.

${ }^{23}$ Bertrand Russell, Sejarah Filsafat Barat, trans. oleh Sigit Jatmiko (dkk.) (Yogyakarta: Pustaka Pelajar, 2007), h. 297. 
Epikuros adalah Diogenes Laertius yang hidup pada abad ke-3 M, meskipun dinilainya masih menyisakan persoalan. Rusell menjelaskan bahwa terdapat dua persoalan pada karya Diogenes tentang Epikuros: pertama, data yang disajikan dinilai hanya memiliki sedikit nilai historis mengenai Epikuros; kedua, adanya kekaburan apakah data yang disajikan merupakan pendapatnya Diogenes sendiri atau hanya berupa kutipan fitnah ${ }^{24}$. Terlepas dari persoalan-persoalan tersebut setidaknya dapat dikemukakan berbagai fakta kehidupan Epikuros.

Epikuros adalah putra dari Neocles dan Chairestrate dan dilahirkan pada tahun 341 S.M. di Samos, tempat ia menghabiskan masa remajanya. Diketahui bahwa ayahnya adalah seorang pendatang dari Athena yang hidup miskin di Samos. Meskipun menghabiskan masa mudanya disana, ia tetap dianggap sebagai orang Athena, sebab ia termasuk anggota dari koloni Athena yang tinggal di Samos. Di usianya yang ke-18 tahun, ia kembali ke Athena. Tapi setelah beberapa saat berselang berada di sana, ia terpaksa harus kembali meninggalkan kota asalnya tersebut untuk ikut mengungsi bersama ayahnya di Colophon. Pengungsian ini dilatarbelakangi oleh pengusiran orang-orang Athena dari Samos, setelah kematian Alexander Agung. ${ }^{25}$

Untuk beberapa saat ditempat pengungsian barunya, Epikuros diketahui memiliki beberapa orang pengikut. Ia menjadi guru filsafat dan berhasil mendirikan sekolah pada tahun 311 S.M., mula-mula di Mitylene lalu kemudian di Lampsacus ${ }^{26}$. Namun, ia memutuskan untuk kembali ke Athena. Tujuan kembalinya ia ke Athena adalah untuk melanjutkan pendidikannya hingga ia menjadi guru filsafat dan mendirikan sekolahnya disana ${ }^{27}$. Sekolah yang didirikannya terletak di taman dekat kediamannya yang disebut kêpos. Murid-muridnya berasal dari berbagai komunitas, mulai dari tiga orang saudaranya Neocles, Chaeredemus dan Aristobulus sahabat-sahabatnya dan anak-

\footnotetext{
${ }^{24}$ Bertrand Russell, Sejarah Filsafat Barat, h. 328-329.

${ }^{25}$ Diogenes Laertius, Lives of Eminent Philosophers, trans. oleh Hicks, vol. 2 (London: William Heinemann, t.t.), h. 529.

${ }^{26}$ Bertrand Russell, Sejarah Filsafat Barat, h. 330.

${ }^{27}$ Diogenes aertius, Lives of Eminent..., h. 529-531.
} 
anak mereka, para budak bahkan kaum pelacur (hetaerae). Muridmuridnya inilah yang nantinya dikenal dengan nama kaum Epikurean.

Epikuros dikenal memiliki kepribadian yang halus dan luhur. Ia adalah sosok yang sederhana, bersikap lemah lembut, baik hati dan sangat setia kawan. Kewibawaannya membuat ia sangat disegani bahkan segala ucapannya dikeramatkan oleh para muridnya. ${ }^{28}$ Namun dibalik sifat-sifat yang dimilikinya itu ia juga dikenal sebagai pribadi yang tegas terhadap sesuatu yang tidak disetujuinya. Epikuros menjalani hidupnya di Athena dengan penderitaan, sebab kesehatannya yang terus-menerus memburuk. Namun dari kehidupannya itu, ia dianggap sebagai orang yang pertama kali menyatakan bahwa manusia mampu berbahagia di tengah penderitaan. ${ }^{29}$ Ia menetap dan mengajar di Athena hingga meninggal pada tahun 271 S.M. di usia 70 tahun.

\section{E. Pemikiran Etika Epikuros}

Epikuros sebenarnya meninggalkan ratusan tulisan yang memuat pemikiran-pemikirannya. Lebih dari 300 tulisan yang ditinggalkan, namun sayangnya hilang dan hanya tersisa beberapa potongan saja. ${ }^{30}$ Ajaran tentang etikanya banyak dijelaskan dalam surat yang dituliskan kepada muridnya, Menoeceus, dan 40 Doktrin Otoritatifnya $^{31}$. Dalam ajaran etikanya, Epikuros melihat kesenangan atau kenikmatan (hêdonê) sebagai ideal tertinggi dan menjadi tujuan hidup manusia. Melihat hal ini, para sarjana filsafat menetapkan corak pemikiran etika Epikuros termasuk dalam teori etika hedonisme. Meskipun demikian, corak etika hedonisme sebelumnya dengan etika hedonisme yang dikembangkan Epikuros memiliki perbedaan yang sangat jelas.

${ }^{28}$ Franz Magnis Suseno, 13 Tokoh Etika: Sejak Zaman Yunani sampai Abad ke-19 (Yogyakarta: Kanisius, 2009), h. 47.

${ }^{29}$ Russell, Sejarah Filsafat Barat, h. 331.

${ }^{30}$ Franz Magnis-Suseno, 13 Tokoh Etika, h. 47-48.

31 Aditi Mitra, "Epicurean Ethics: A Relook," American International Journal of Contemporary Research 5, no. 1 (Januari 2015), h. 98. 
Dalam filsafat Yunani, corak pemikiran etika hedonisme telah ditemukan dalam pemikiran filsuf pendahulu Epikuros, Aristippos. Ia adalah filsuf dari Kyrene dan merupakan murid dari Sokrates. Dalam pemikirannya, Aristippos menetapkan bahwa ideal tertinggi dalam kehidupan manusia adalah kesenangan, sebab sejak kecil manusia merasa tertarik dengan hal itu dan berusaha menjauhi ketidaksenangan. Mereka tidak akan mencari hal yang lain ketika kesenangan tersebut telah tercapai. Tolok ukur kesenangan menurutnya hanya dilihat dari hal-hal yang bersifat indriawi, individual dan aktual kini dan di sini. Namun, ia tetap mengakui bahwa dalam memanfaatkan kesenangan itu tetap dibutuhkan pengendalian diri. Ia juga mengatakan bahwa manusia harus membatasi diri pada kesenangan yang diperoleh dengan mudah tanpa perlu bersusah payah. ${ }^{32}$

Berbeda dengan Aristippos yang membatasi makna kesenangan hanya pada hal-hal yang bersifat indriawi, maka tidak demikian dengan pemaknaan Epikuros. Ia tidak menyangkal bahwa kenikmatan indriawi itu penting. Namun, seperti tubuh yang membutuhkan kenikmatan indrawi, jiwa manusia juga membutuhkan kenikmatan. Hal ini sebagaimana ditemukan dalam suratnya kepada Menoeceus:

"When we say, then, that pleasure is the end and aim, we do not mean the pleasures of the prodigal or the pleasures of sensuality, as we are understood to do by some through ignorance, predujice, or wilful mispresentation. By pleasure we mean the absence of pain in the body and trouble in the soul. $" 33$

Kenikmatan yang dimaksudkan Epikuros dalam hal ini adalah ketenangan jiwa yang diistilahkan dengan ataraxia. Ketenangan jiwa inilah yang dianggapnya lebih penting dari sekadar kenikmatan indrawi. Kenikmatan indrawi hanya sebatas pada pemenuhan keinginan alami yang dibutuhkan tubuh agar tetap dalam keadaan sehat. Dalam hal ini sebagaimana yang tertera dalam suratnya kepada

\footnotetext{
${ }^{32}$ K. Bertens, Etika, h. 183-184.

${ }^{33}$ Diogenes Laertius, Lives of Eminent..., h. 657.
} 
Menoeceusia menjelaskan beberapa macam keinginan manusia. Secara keseluruhan ada tiga keinginan manusia: (1) keinginan alami dan sangat diperlukan (natural and indispensable); (2) keinginan alami dan boleh jadi diperlukan (natural and perhaps indispensable); dan (3) keinginan yang sia-sia (vain). Sebagai contoh jenis keinginan yang pertama adalah kebutuhan alami manusia untuk makan, kedua adalah keinginan untuk menikmati makanan yang enak dan ketiga adalah keinginan untuk memperoleh kekayaan. Bagi Epikuros, keinginan pertamalah yang dituntut untuk dipenuhi dan dipuaskan. Namun, pemuasan itu tidak dilakukan dengan cara yang berlebihan. ${ }^{34}$

Dari sini kita melihat bahwa Epikuros menganjurkan untuk menjalani hidup secara sederhana. Orang yang bijaksana menurutnya adalah orang yang sedapat mungkin mampu terlepas dari keinginankeinginan yang tidak begitu penting bahkan sia-sia. Kehidupan yang sederhana tidak sekadar diungkapkan melalui ajarannya, namun secara langsung diaplikasikan dalam kehidupannya. Dalam salah satu keterangan dijelaskan bahwa ia menjalani hidupnya hanya dengan makan roti dan sedikit keju pada saat-saat pesta ${ }^{35}$. Ambisi untuk memperoleh kekayaan adalah sesuatu yang sia-sia dan hanya mendatangkan kegelisahan apabila keinginan tersebut tidak tercapai.

Lebih jauh Epikuros mendefinisikan kenikmatan yang mendatangkan ketenangan bagi jiwa sebagai keadaan negatif, yaitu tidak adanya rasa sakit dan kecemasan atau kegelisahan. Dalam hal ini ia memiliki rasa prihatin yang besar terhadap penderitaan dan kecemasan yang dialami manusia sehingga beban itu dianggapnya akan lebih ringan ketika orang-orang bersedia mengikuti filsafatnya. Mengenai hal ini Russell menulis:

"Ini adalah filsafatnya orang sakit-sakitan, yang disusun agar sesuai bagi dunia di mana kebahagiaan yang sarat petualangan telah sulit dirasakan. Sedikit makan, sebab khawatir sakit lambung; sedikit minum, sebab cemas akan hari esok; menjauhi politik, percintaan, dan segala kegiatan

${ }^{34}$ K. Bertens, Etika, hlm. 184-185. Lihat juga Aditi Mitra, "Epicurean Ethics, h. 98.

${ }^{35}$ Bertrand Russell, Sejarah Filsafat Barat, h. 334. 
yang terlampau bergairah; jangan mengikatkan diri pada perkawinan dan memiliki anak; di dalam kehidupan batinmu, ajarilah dirimu untuk lebih banyak merenungkan kenikmatan dari pada penderitaan." ${ }^{\text {, }}$

Mengenai kecemasan ini, ia menambahkan dua sumber kecemasan lain yang harus disingkirkan agar manusia mampu mencapai ataraxia. Dua kecemasan tersebut adalah kecemasan agama, yaitu ketakutan terhadap dewa dan kecemasan akan kematian. Kecemasan tersebut dianggapnya sebagai kecemasan yang tidak beralasan dan tidak masuk akal. Untuk menjelaskan argumennya ia terarahkan menuju filsafat teoretis, meliputi kajian metafisika, meskipun ia sendiri tidak memiliki minat terhadap bidang ini.

Rasa takut terhadap dewa dianggap Epikuros tidak berdasar sebab para dewa tidak ada hubungannya dengan manusia dan tindakannya. Mereka adalah entitas abadi yang tinggal dengan segala ketenangan dan kebahagiaannya tanpa perhatian sama sekali terhadap manusia. Maka tidak masuk akal jika manusia berupaya agar para dewa bersikap baik dan bersedia meredam kemurkaan mereka. Mereka sedemikian bijaksananya sehingga tidak mungkin terkejut dan gelisah jiwanya disebabkan oleh tindakan manusia. Oleh sebab itu, menurutnya manusia tidak perlu takut kepada para dewa dalam usahanya untuk meraih kenikmatan. Keyakinan ini dipegang teguh oleh Epikuros dan murid-muridnya sebab dipengaruhi oleh ajaran Demokritos. $^{37}$

Demokritos dikenal sebagai filsuf atomis. Ia menjelaskan bahwa seluruh realitas terbentuk dari gugusan atom. Baginya, atom hanya memiliki bentuk dan ukuran sehingga memungkinkan atomatom tersebut bergerak kesegala arah. Meskipun Epikuros juga mengajarkan tentang atom dan dipengaruhi oleh Demokritos, ia memiliki pandangan yang berbeda. Menurutnya, atom tidak hanya memiliki bentuk dan ukuran, melainkan juga memiliki berat. Hal ini berkonsekuensi pada arah gerak atom yang memiliki kecenderungan

${ }^{36}$ Ibid., h. 335.

37 Simon Petrus L. Tjahjadi, Petualangan Intelektual (Yogyakarta: Kanisius, 2016), h. 83. 
untuk bergerak ke bawah (jatuh). Tetapi atom-atom tersebut tidak selalu jatuh ke bawah, melainkan sedikit melenceng dari garis lurus tanpa diketahui penyebabnya. ${ }^{38}$

Atas dasar pandangan tentang gerak atom tersebut, Epikuros sampai pada kesimpulan bahwa disatu pihak berbagai kejadian alam berlangsung secara mekanis. Dari sinilah ia berkesimpulan bahwa para dewa memang tidak disangkal perihal eksistensinya, tetapi mereka tidak ikut campur tangan terhadap gerak dan berbagai kejadian lainnya di alam semesta yang bersifat mekanis ini. Pandangan Epikuros ini bermuara pada kesimpulan bahwa ia menganut paham deisme. Di sisi lain, melencengnya gerakan atom tersebut membawa Epikuros kepada keyakinan tentang ketiadaan takdir. Artinya, Para dewa tidak berperan dalam menentukan tindakan dan nasib manusia. Oleh sebab itu, manusia memiliki kehendak yang bebas dalam menentukan segala tindakannya dan mempertanggungjawabkannya. ${ }^{39}$

Kecemasan akan kematian menurut Epikuros juga harus disingkirkan, sebab dianggapnya tidak masuk akal. Menurutnya, kemampuan untuk merasakan sesuatu terjadi akibat adanya hubungan antara atom-atom tubuh dan atom-atom jiwa. Kematian membuat hubungan atom-atom tersebut menghilang, sehingga kemampuan untuk merasakan sesuatu pun ikut menghilang. Maka kematian tidak ada hubungannya dengan mereka yang masih hidup. Selama manusia memiliki kemampuan untuk merasakan sesuatu, maka kematian itu tidak ada. Ketika kematian datang menimpa manusia, ia tidak akan merasakan apapun lagi sebab ia sudah tidak ada. Lalu mengapa kematian harus dicemaskan. ${ }^{40}$

Demikian pemikiran etika Epikuros menjadikan kesenangan atau kenikmatan sebagai tema sentralnya. Kenikmatan yang terbebas dari rasa sakit dan kecemasan. Untuk itu manusia harus memiliki kemampuan untuk mempertimbangkan segala pilihan dan tindakannya agar terhindar dari penderitaan dan kecemasan itu.

\footnotetext{
${ }^{38}$ Harun Hadiwijono, Sari Sejarah Filsafat Barat I, h. 56.

${ }^{39}$ Simon Petrus L. Tjahjadi, Petualangan Intelektual, h. 83-84.

${ }^{40}$ Ibid., h. 84.
} 
Kemampuan tersebut diistilahkan sebagai prudence (diterjemahkan dari kata dalam bahasa Yunani, phronesis). Epikuros bahkan menganggap prudence lebih mulia dibandingkan filsafat ${ }^{41}$. Epikuros dan para muridnya dikenal tidak memiliki minat terhadap persoalanpersoalan politik dan cenderung menarik diri dari kehidupan ramai. Hal ini semata-mata untuk menghindari resiko terganggunya ketenangan jiwa mereka. Di sini jelas terlihat bahwa ajaran etikanya bersifat individualistik, namun tidak bersifat egoistis. Hal ini terlihat dari ajarannya bahwa berbuat baik sering lebih menyenangkan dari pada sekadar menerima kebaikan ${ }^{42}$. Ia pun tidak sepenuhnya menghindari kehidupan sosial, sebab baginya hubungan sosial yang paling aman adalah persahabatan. ${ }^{43}$

\section{F. Relevansi Pemikiran Etika Epikuros}

Setiap konsep yang digagas oleh pemikir tentunya tidak lahir dari ruang hampa. Ia tidak mungkin lahir tanpa situasi yang melatarbelakangi gagasan tersebut dikonsepsikan, yaitu berupa situasi sosial, budaya, agama dan lain-lain. Hal tersebutlah yang dinamakan sebagai konteks. Konteks inilah yang menentukan bagaimana seseorang atau sekelompok orang mengekspresikan dirinya, baik dalam bernalar maupun bertindak. Sejalan dengan hal itu, maka dapat dikatakan bahwa lahirnya pemikiran etika Epikuros pasti dilatarbelakangi oleh situasi tertentu.

Namun, persoalannya kemudian adalah apakah kita sebagai pembaca (reader) dapat selalu mengetahui konteks yang melingkupi setiap tokoh pemikir? Apalagi tokoh tersebut diketahui hidup ratusan atau bahkan berabad-abad yang lalu. Jawabannya tentu tidak. Keterangan mengenai konteks tersebut sangat bertalian erat dengan data historis. Data tersebut bisa saja diperoleh dari keterangan langsung tokoh yang ditulis dalam bentuk otobiografi atau disinggung meskipun hanya sedikit dalam karya-karyanya, bisa juga diperoleh dari penyelidikan seorang ahli terhadap tokoh-tokoh lain yang

\footnotetext{
${ }^{41}$ Laertius, Lives of Eminent..., h. 657.

${ }^{42}$ Franz Magnis-Suseno, 13 Tokoh Etika, h. 50.

${ }^{43}$ Bertrand Russell, Sejarah Filsafat Barat, h. 334.
} 
sezaman atau objek sejarah lainnya yang memiliki keterkaitan dengan tokoh yang dikaji. Oleh sebab itu, dapat dikatakan bahwa pengetahuan tentang konteks ini tergantung sejauh mana dan selengkap apa data historis yang tersedia.

Dalam kajian Epikuros ini, penulis beruntung dapat menemukan data historis mengenai konteks gagasan pemikiran etika Epikuros meskipun masih terbilang minim. Berdasarkan data tersebut, gagasan etika Epikuros lahir sebagai usaha untuk membebaskan manusia dari berbagai kecemasan bahkan penderitaan yang disebabkan utamanya oleh ketakutan terhadap dewa dan kematian. Menurutnya, ketakutan tersebut membuat kebebasan manusia untuk bertindak menjadi terbelenggu, sebab selalu harus terpaku dengan keinginan para dewa. Padahal kehidupan manusia termasuk tindakan dan nasibnya tidak ada kaitannya dengan para dewa. Belum lagi kecemasan karena dibayang-bayangi oleh kematian. Kehidupan bangsa Yunani pada zaman Helenistis memang kental diwarnai dengan keyakinan terhadap astrologi yang bersumber dari agama pagan. Keyakinan ini tidak hanya menjangkiti masyarakat awam, melainkan juga para filsuf. Semangat pembebasan ini tidak berhenti pada Epikuros saja, melainkan terus dilanjutkan oleh muridnya, kaum Epikurean. ${ }^{44}$

Agar pemikiran etika Epikuros ini tidak sekadar menjadi peninggalan antik dalam sejarah filsafat, maka ia perlu digaungkan kembali di masa sekarang. Hal ini dimaksudkan untuk menjadikan konsep tersebut sebagai acuan dalam membaca atau bahkan menyelesaikan problem-problem aktual-kekinian, khususnya yang berkaitan dengan problem etis. Cara yang ditempuh salah satunya adalah dengan menentukan poin-poin yang dianggap penting dan paling utama dalam pemikiran etikanya lalu mendialogkannya dengan isu-isu tertentu.

Menurut penulis, poin penting yang dapat diambil dari pemikiran etika Epikuros adalah sikap prudence. Secara sederhana istilah ini biasa diartikan sebagai "kebijaksanaan". Namun dalam konteks ajaran Epikuros, istilah ini lebih tepat jika dimaknai dengan

${ }^{44}$ Bertrand Russell, Sejarah Filsafat Barat, h. 308-309. 
"kewaspadaan"45. Sikap tersebut membuat manusia mampu mempertimbangkan dengan penuh kematangan segala tindakannya agar terhindar dari penderitaan atau kecemasan. Hal tersebut akan membuat jiwanya pun menjadi tenang. Sikap ini juga mengarahkan manusia untuk bertindak hanya sesuai dengan kebutuhan, dengan demikian tidak melampaui batas dalam memuaskan kebutuhannya tersebut. Poin penting inilah yang kemudian dapat dihubungkan dengan isu-isu tertentu yang menyangkut problem etis.

Salah satu isu aktual-kekinian yang dapat dijadikan sebagai contoh adalah media sosial (social media). Media sosial secara sederhana dapat didefinisikan sebagai alat berupa kelompok aplikasi, yang digunakan untuk berkomunikasi dalam proses sosial berbasis internet. Adanya media sosial ini memudahkan para penggunanya untuk berbagi pesan dan informasi baik dalam bentuk teks, suara maupun video. Secara umum, media sosial terdiri dari tiga unsur utama, yaitu infrastruktur informasi, konten media serta produsen dan konsumen media ${ }^{46}$. Ia merupakan produk yang lahir dari perkembangan ilmu pengetahuan dan teknologi yang pesat, khususnya dalam bidang informasi dan komunikasi. Perlu disadari bahwa kemajuan ilmu pengetahuan dan teknologi bersifat ambivalen, yaitu memiliki dampak positif sekaligus negatif ${ }^{47}$. Hal demikian juga berlaku pada media sosial. Di satu sisi ia mendatangkan manfaat bagi penggunanya, yaitu memungkinkan mereka mengakses dan menyebarkan informasi dengan cepat di mana dan kapan saja. Ia menjadi sarana untuk memperluas jangkauan hubungan sosial penggunanya. Singkatnya, ia memberikan kemudahan untuk "menjelajahi" dunia. Namun, di balik berbagai kemudahan yang ditawarkan, media sosial juga tentunya memiliki dampak negatif tergantung pada maksud penggunaannya. Melihat peranan manusia

$45 \mathrm{http} / / /$ en.oxforddictionaries.com/definition/prudence, diakses pada tanggal 24 September 2018.

${ }^{46}$ Dedi Rianto Rahadi, "Perilaku Pengguna dan Informasi Hoax di Media Sosial," Jurnal Manajemen dan Kewirausahaan 5, no. 1 (30 Juni 2017), https://doi.org/10.26905/jmdk.v5i1.1342., h. 60.

${ }^{47}$ K. Bertens, Sejarah Filsafat Yunani, h. 222. 
sebagai pengguna media sosial, maka ia jelas berkaitan dengan persoalan etis.

Di antara isu-isu aktual mengenai dampak negatif penggunaan media sosial adalah maraknya penyebaran berita palsu atau bohong (hoax). Menyebarnya hoax bisa disebabkan oleh berbagai faktor, salah satunya adalah budaya share, atau kebiasaan masyarakat yang ingin cepat berbagi informasi. ${ }^{48}$ Berita-berita yang tidak jelas asalusul dan kebenarannya begitu mudah dibagikan ulang kepada orang lain tanpa terlebih dahulu dilakukan penyelidikan terhadap berita tersebut. Penyebaran berita ini biasanya diikuti dengan penggunaan kata atau kalimat yang sifatnya provokatif seperti "sebarkanlah", "share ke yang lain" atau "bagikan", bahkan tidak segan menggunakan kata atau kalimat yang intimidatif bila berita tersebut tidak dibagikan ulang, misalnya disumpahi atau didoakan mendapat petaka dan kesialan. ${ }^{49}$ Faktor lain penyebaran hoax adalah karena kepentingan tertentu, misalnya demi kepentingan kontestasi politik. Para pendukung calon tertentu memproduksi hoax dengan maksud untuk menjatuhkan dan merusak citra calon yang lain. Pada akhirnya, kedua kubu yang berseberangan saling melempar cacian dan fitnah. Hal tersebut diistilahkan dengan cyberwar.

Mengawali penjelasan mengenai hubungan ajaran etika Epikuros dengan problem media sosial, maka pertanyaan yang pertama kali penting untuk diajukan adalah "Perlukah media sosial bagi manusia di zaman ini?" Pendapat mengenai perlu tidaknya hal tersebut didasarkan pada ajaran Epikuros tentang klasifikasi keinginan manusia, menyangkut mana yang perlu, boleh jadi perlu dan sia-sia. Untuk menjawab hal ini, tentunya tidak tepat bila kita menjadikan konteks zaman Epikuros sebagai acuan. Hal ini disebabkan konteks pada masanya yang terjadi berabad-abad yang

48 Vibriza Juliswara, "Mengembangkan Model Literasi Media yang Berkebhinnekaan dalam Menganalisis Informasi Berita Palsu (Hoax) di Media Sosial," Jurnal Pemikiran Sosiologi 4, no. 2 (6 November 2017): 142-64, https://doi.org/10.22146/jps.v4i2.28586. h. 148.

49 Mulawarman Mulawarman dan Aldila Dyas Nurfitri, "Perilaku Pengguna Media Sosial beserta Implikasinya Ditinjau dari Perspektif Psikologi Sosial Terapan," Buletin Psikologi 25, no. 1 (23 Juni 2017): 36 - 44, https://doi.org/10.22146/buletinpsikologi.22759, h. 43. 
laluberbeda dengan konteks kita di zaman ini. Dengan kata lain, analisis mengenai kebutuhan manusia pada zamannya berbeda dengan kebutuhan manusia di zaman sekarang. Oleh sebab itu, konteks kitalah yang seharusnya menjadi acuan dalam melakukan penilaian tentang kebutuhan ini.

Penting untuk disadari bahwa kita telah memasuki era digital. Segala aktivitas manusia hampir tidak bisa lepas dari proses digitalisasi. Proses ini tidak boleh tidak diakui banyak memberikan kemudahan bagi manusia. Sementara itu, kebutuhan akan informasi yang semakin besar, berbanding lurus dengan kemudahan untuk mengakses jutaan bahkan miliaran informasi. Tidak hanya akses terhadap informasi, kemudahan dalam berkomunikasi juga semakin dapat dirasakan. Berbagai kemudahan ini tentu tidak lepas dari peran media sosial. Maka dengan kenyataan tersebut, dapat disimpulkan bahwa media sosial dinilai perlu bagi manusia.

Setelah disimpulkan bahwa media sosial merupakan sesuatu yang perlu, maka pertanyaan selanjutnya adalah "Bagaimana seharusnya pengguna memanfaatkan media sosial?" Dalam hal inilah manusia sebagai pengguna harus memiliki sikap prudence. Media sosial harus dimanfaatkan sesuai dengan fungsinya, yaitu untuk memenuhi kebutuhan akan informasi dan komunikasi. Tidak tepat jika media sosial dimanfaatkan secara berlebihan, apalagi ketika fungsinya diarahkan kepada hal lain yang sebenarnya kurang penting atau bahkan tidak penting, dan melenceng dari fungsi utamanya sebagai alat untuk sekadar memenuhi kebutuhan informasi dan komunikasi. Selanjutnya, seorang pengguna sedapat mungkin menarik diri atau lebih tepatnya menahan diri agar tidak terlibat dengan segala problem yang terjadi di media sosial. Termasuk juga dalam hal ini menahan diri untuk menyebarkan pesan-pesan yang belum jelas kebenarannya, agar tidak turut menjadi bagian dari mata rantai penyebaran hoax. Keterlibatan yang terlalu dalam terhadap problem-problem yang terjadi di media sosial, hanya akan menambah beban pikiran yang berpotensi mengganggu ketenangan jiwa. Demikian contoh kecil penerapan pemikiran etika Epikuros terhadap isu-isu tertentu yang berkaitan dengan persoalan etis. 


\section{G. Kesimpulan}

Epikuros dalam pemikiran Etikanya menetapkan kesenangan atau kenikmatan (hêdonê) sebagai ideal tertinggi dalam kehidupan manusia. Kenikmatan tersebut tidak hanya dari aspek indriawi, melainkan juga kenikmatan jiwa, yang disebut sebagai ataraxia (ketenangan jiwa). Cara yang dilakukan untuk mencapai ketenangan jiwa adalah dengan berusaha menghindari penderitaan dan kecemasan. Untuk mewujudkannya manusia harus memiliki sikap kewaspadaan (phronesis atau prudence), dengan sikap kewaspadaan akan menuntun manusia supaya mempertimbangkan dengan matang segala tindakannya agar terhindar dari penderitaan atau kecemasan. Konsep etika Epikuros ini sangat relevan apabila diterapkan dalam penggunaan media sosial, karena jika setiap diri mempunyai sikap kewaspadaan baik dalam menerima informasi maupun menyebarluaskannya, maka problem media sosial khususnya mengenai hoax akan dapat dikurangi.

\section{Daftar Rujukan}

Bertens, K. Etika. Yogyakarta: Kanisius, 2013.

. Sejarah Filsafat Yunani. Yogyakarta: Kanisius, 1989.

Hadiwijono, Harun. Sari Sejarah Filsafat Barat I. Yogyakarta: Kanisius, 2001.

Iqbal, Imam. "Menjelajahi Etika: Dari Arti Hingga Teori." Dalam Etika: Perspektif, Teori dan Praktik. Yogyakarta: FA Press, 2016.

Juliswara, Vibriza. "Mengembangkan Model Literasi Media yang Berkebhinnekaan dalam Menganalisis Informasi Berita Palsu (Hoax) di Media Sosial.” Jurnal Pemikiran Sosiologi 4, no. 2 (6 November 2017): 142-64.

Laertius, Diogenes. Lives of Eminent Philosophers. Diterjemahkan oleh R. D. Hicks. Vol. 2. London: William Heinemann, t.t.

Mitra, Aditi. "Epicurean Ethics: A Relook." American International Journal of Contemporary Research 5, no. 1 (Januari 2015). 
Mulawarman, Mulawarman, dan Aldila Dyas Nurfitri. "Perilaku Pengguna Media Sosial beserta Implikasinya Ditinjau dari Perspektif Psikologi Sosial Terapan.” Buletin Psikologi 25, no. 1 (23 Juni 2017): 36 - 44.

Rahadi, Dedi Rianto. "Perilaku Pengguna dan Informasi Hoax di Media Sosial." Jurnal Manajemen dan Kewirausahaan, Vol. 5, no. 1 (30 Juni 2017).

Rapar, Jan Hendrik. Pengantar Filsafat. Yogyakarta: Kanisius, 2015.

Russell, Bertrand. Sejarah Filsafat Barat. Diterjemahkan oleh Sigit Jatmiko. Yogyakarta: Pustaka Pelajar, 2007.

Suseno, Franz Magnis. 13 Tokoh Etika: Sejak Zaman Yunani sampai Abad ke-19. Yogyakarta: Kanisius, 2009.

_. Etika Dasar: Masalah-Masalah Pokok Filsafat Moral. Yogyakarta: Kanisius, 2014.

Tim Penyusun Kamus Pusat Bahasa. Kamus Bahasa Indonesia. Jakarta: Pusat Bahasa, 2008.

Tjahjadi, Simon Petrus L. Petualangan Intelektual. Yogyakarta: Kanisius, 2016.

Weij, P. A. Van der. Filsuf-Filsuf Besar Tentang Manusia. Diterjemahkan oleh K. Bertens. Jakarta: PT Gramedia Pustaka Utama, 2017.

Zaleski, Jeff. Spiritual Cyberspace. Bandung: Mizan, 1999.

http://en.oxforddictionaries.com/definition/prudence, diakses pada tanggal 24 September 2018 pukul 21.07 WIB. 